\title{
EFFECT OF PHOSPHATE ROCK AND TRIPLESUPERPHOSPHATE ON GROWTH AND LEAF N, P AND K CONTENTS OF GROUNDNUT (ARACHIS HYPOGAEA L.) GROWN ON A CLAY SOIL
}

\author{
Elsheikh1, M.A.; A.M.A. El-Tilib²; E.A. E. Elsheikh² and A.H. Awad Elkarim²
}

1. Laboratory of Environmental Soil Science, Faculty of Agriculture, Ehime University, 3-5-7 Tarumi, Matsuyama, Ehime, 790-8566, Japan.

2. Department of Soil and Environment Sciences, Faculty of Agriculture, University of Khartoum, Shambat, Sudan.

Keywords: Rock phosphates, Triplesuperphosphates, Ground nut, Clay soil

\begin{abstract}
A pot experiment was carried out to investigate the agricultural value of a local phosphate rock (PR) as a source of plant phosphorus compared with that of the currently imported triplesuperphosphate (TSP) .The PR was applied at the rate of 0,55 , and $110 \mathrm{~kg} \mathrm{P}_{2} \mathrm{O}_{5}$ /ha and the TSP was at the rate of 0,45 and $90 \mathrm{~kg} \mathrm{P}_{2} \mathrm{O}_{5} / \mathrm{ha}$. The growth and leaf contents of $\mathrm{N}, \mathrm{P}$ and $\mathrm{K}$ of groundnut (Arachis hypogaea L.) grown on a clay soil were measured. The experiment continued for two seasons. Phosphatic fertilizers are of low recovery; therefore, they can remain for the next crop. Thus, the pots of the first season were set to study the residual effect of phosphorus in the second season. The results indicated that PR and TSP significantly $(\mathrm{P}>0.05)$ increased dry weights of shoot and root, leaf contents of $\mathrm{N}, \mathrm{P}$ and available soil phosphorus. However, plant height was significantly increased by TSP only. The leaf content of $\mathrm{K}$ was neither affected by PR nor TSP application. The results showed a positive effect of the residual PR and TSP on the measured parameters. Moreover, the results revealed that the plant measurements obtained from PR treatments were comparable to those obtained from TSP treatments which indicate that PR can be used as a potential source of phosphorus fertilizer.
\end{abstract}

\section{INTRODUCTION}

Phosphorus is an essential element in plant nutrition. It is often deficient and of low solubility and, therefore, it has to be added as a fertilizer. In Sudan, with a possible exception of nitrogen, phosphorus is the main limiting factor in crop production (El Saeed 1997). This was the concern of many research workers in Sudan who pointed out the good response of crops to phosphorus addition (El Tilib et al 2003). Phosphate rock (PR) is the base for the production of all water soluble phosphorus fertilizers. Finely ground PR ore had been applied directly to the soil as a low-cost fertilizer as an alternative of the water soluble phosphate fertilizers where indigenous deposits of PRs ore located. Phosphorus fertilizers normally have a high carry over effects from one year to the next. Regarding this, residual effect of PR was studied by many workers (Abdalla 1993 and El Saeed 1997).

In Sudan, groundnut is produced on large areas under rainfed and irrigation systems. Mostly, the crop is not fertilized in spite of the inherently low soil fertility in terms of nitrogen and phosphorus. However, experiments conducted in different parts of the country gave an erratic and inconsistent results (Hago, Personal Communication, 2005). Triplesuperphosphate, as a source of phosphorus in Sudan agriculture, is an imported commodity, hence, it is expensive. It is, therefore, necessary to try a local and cheaper source of phosphorus. This study was meant to try a local phosphate rock as 
source of plant phosphorus. Phosphate Rock is present in different parts of Sudan in considerable amounts, particularly, in Nuba Mountains " $\mathrm{Ku}$ run", Western of Sudan (Abdalla 1993). The aim of this work was to determine the effect of PR and TSP and their residual effect on growth and N, P and $\mathrm{K}$ leaf contents of groundnut (Arachis hypogaea $\mathrm{L})$.

\section{MATERIALS AND METHODS}

Pot experiments were carried out at the Faculty of Agriculture, University of Khartoum, Shambat (latitudes $15^{\circ} 40 \mathrm{~N}$; longitude $32^{\circ} 32 \mathrm{E}^{\circ}$ ) for two summer seasons (2001 and 2002) to examine the effect of PR and TSP on growth and leaf N, P and $\mathrm{K}$ contents of groundnut (Arachis hypogaea L)grown on Shambat clay soil. Along with this, another experiment was conducted in the second season (2002) to study the residual effect of the applied phosphatic fertilizers of the first season. Surface samples of Shambat soil, $(0-30 \mathrm{~cm})$ were used in this study. The physical and chemical properties of the soil used were as follows: $\mathrm{pH}=$ 8.1; $\mathrm{ECe}=0.52 \mathrm{dSm}^{-1} ; \mathrm{K}=0.1 \mathrm{meq} / 1 ; \mathrm{P}=3.3 \mathrm{ppm}$; $\mathrm{N}=0.056 \%$; clay $=54.1 \%$. Plastic pots $(33 \mathrm{~cm} \mathrm{di-}$ ameter and $23 \mathrm{~cm}$ deep) were used as experimental units and each pot was filled with $10 \mathrm{~kg}$ soil. Uniform size seeds of groundnut cultivar $\mathrm{MH}$ 383 were sown in the first week of July in all growing seasons. Five seeds were sown in each pot, and, then thinned to two plants per pot after two weeks from sowing. The treatments were arranged in a factorial completely randomized design replicated thrice. The treatments comprised three PR levels $\left(0,55\right.$ and $\left.110 \mathrm{~kg}_{2} \mathrm{O}_{5} / \mathrm{ha}\right)$ and three TSP levels $\left(0,45\right.$, and $\left.90 \mathrm{~kg} \mathrm{P}_{2} \mathrm{O}_{5} / \mathrm{ha}\right)$. The local PR used in this study was collected from Jabel Kurun in the Nuba Mountains, South Kordofan State, Western Sudan. The two phosphatic fertilizers were applied at sowing by band method. Seedlings were either inoculated or uninoculated with Bradyhizobium sp. strain TAL 1371 obtained from NIFTAL project in Hawaii, U.S.A. The pots were irrigated with tap water at $60 \%$ field capacity every three days. Plants were harvested on the third week of November of each growing season. The parameters measured were plant height, shoot and root dry weights. Leaf mineral contents of $\mathrm{N}$, $\mathrm{P}, \mathrm{K}$ and available soil phosphorus were determined according to procedures described by Tandon (1993).

\section{RESULTS AND DISCUSSION}

Application of Bradyhizobium sp. showed no significant effect on all measured parameters (data not shown). The results of this study showed that the plant height was significantly increased (P>0.05) by addition of TSP in both seasons (Table 1). Plant height is an important growth factor. Hago et al (2002) reported similar effects for phosphorus fertilizers on Roselle (Hibiscus sabdariffa var. sabdariffa L.). This could be attributed to the positive effect of water soluble phosphatic fertilizers on plant photosynthesis and, hence, plant height. The effect of PR addition on plant height was not significant (Table 1) . This may be due to the relatively low solubility of the phosphorus in PR and, hence, the phosphorus level in the root sorption zone is low, particularly, in early growth stages. It may also be attributed to the low development of plant compared with its rapid growth when soluble form of phosphorus is applied (Hammond et al 1986). There were no significant differences between the overall effect of PR and TSP on plant height.

Table 1. The effect of phosphate rock and triplesuperphosphate on plant height $(\mathrm{cm})$

\begin{tabular}{|c|c|c|c|}
\hline $\begin{array}{l}\text { Treatment } \\
\mathrm{kg} \mathrm{P}_{2} \mathrm{O}_{5} \mathrm{ha}^{-1}\end{array}$ & $\begin{array}{l}\text { First sea- } \\
\text { son }\end{array}$ & $\begin{array}{l}\text { Second } \\
\text { season }\end{array}$ & $\begin{array}{c}\text { Residual } \\
\text { effect }\end{array}$ \\
\hline \multicolumn{4}{|c|}{ Phosphate Rock (PR) } \\
\hline Control & $15.3 \mathrm{a}$ & $13.7 \mathrm{a}$ & $13.8 \mathrm{~b}$ \\
\hline 55 & $15.1 \mathrm{a}$ & $14.0 \mathrm{a}$ & $14.6 \mathrm{a}$ \\
\hline 110 & $15.4 \mathrm{a}$ & $14.0 \mathrm{a}$ & $18.4 \mathrm{a}$ \\
\hline $\mathrm{LSD}_{0.05}$ & 0.81 & 0.59 & 0.71 \\
\hline \multicolumn{4}{|c|}{ Triplesuperphosphate (TSP) } \\
\hline Control & $14.2 b$ & $13.2 \mathrm{~b}$ & $13.5 \mathrm{c}$ \\
\hline 45 & $15.8 \mathrm{a}$ & $14.0 \mathrm{a}$ & $14.4 \mathrm{~b}$ \\
\hline 90 & $16.0 \mathrm{a}$ & $14.4 \mathrm{a}$ & $15.2 \mathrm{a}$ \\
\hline $\mathrm{LSD}_{0.05}$ & 0.81 & 0.59 & 0.17 \\
\hline
\end{tabular}

Means with similar letter(s) in each column are not significantly different at 0.05 probability level according to LSD. 
Application of PR and TSP significantly $(\mathrm{P}>0.05)$ increased shoot and root dry weights in both seasons (Table 2). The positive effect of PR and TSP on shoot and root dry weights were reported by many workers (Hago \& Osman 1999; Hago et al 2002 and Osman et al 2002). Shoot and root dry weights, which are ultimate produce of plant height and branch number, were increased with phosphorus fertilizers.

Table 2. The effect of phosphate rock and triplesuperphosphate on shoot dry weight (S.D.W) and root dry weight (R.D.W) (g/pot)

\begin{tabular}{|c|c|c|c|c|c|c|}
\hline \multirow{2}{*}{$\begin{array}{c}\text { Treatment } \\
\mathrm{Kg} \mathrm{P}_{2} \mathrm{O}_{5} \mathrm{ha}^{-1}\end{array}$} & \multicolumn{2}{|c|}{ First season } & \multicolumn{2}{|c|}{ Second season } & \multicolumn{2}{|c|}{ Residual Effect } \\
\hline & S.D.W & R.D.W & S.D.W & R.D.W & S.D.W & R.D.W \\
\hline & \multicolumn{6}{|c|}{ Phosphate Rock (PR) } \\
\hline Control & $29.0 \mathrm{~b}$ & $0.76 \mathrm{c}$ & $23.8 \mathrm{~b}$ & $0.64 \mathrm{~b}$ & 26.8 & $0.66 b$ \\
\hline 55 & $29.80 \mathrm{a}$ & $0.81 \mathrm{~b}$ & $26.5 \mathrm{a}$ & $0.67 \mathrm{a}$ & $29.5 \mathrm{a}$ & $0.73 \mathrm{a}$ \\
\hline 110 & $29.9 \mathrm{a}$ & $0.87 \mathrm{a}$ & $26.6 \mathrm{a}$ & $0.67 \mathrm{a}$ & $30.1 \mathrm{a}$ & $0.73 \mathrm{a}$ \\
\hline \multirow[t]{2}{*}{$\mathrm{LSD}_{0.05}$} & 0.74 & 0.06 & 2.30 & 0.03 & 1.8 & 0.64 \\
\hline & \multicolumn{6}{|c|}{ Triplesuperphosphate (TSP) } \\
\hline Control & $28.7 b$ & $0.75 b$ & $23.90 b$ & $0.61 \mathrm{~b}$ & $27.7 b$ & $0.68 \mathrm{a}$ \\
\hline 45 & $29.9 \mathrm{a}$ & $0.84 \mathrm{a}$ & $6.86 \mathrm{ab}$ & $0.66 \mathrm{a}$ & $27.7 b$ & $0.69 \mathrm{a}$ \\
\hline 90 & $30.1 \mathrm{a}$ & $0.85 \mathrm{a}$ & $26.80 \mathrm{a}$ & $0.67 \mathrm{a}$ & $31.2 \mathrm{a}$ & $6.70 \mathrm{a}$ \\
\hline $\mathrm{LSD}_{0.05}$ & 0.74 & 0.06 & 2.30 & 0.03 & 1.82 & 0.06 \\
\hline
\end{tabular}

Means with similar letter(s) in each column are not significantly different at 0.05 probability level according to LSD.
The results showed that application of PR or TSP significantly $(\mathrm{P}>0.05)$ improved the leaf content of nitrogen and phosphorus in both seasons (Table 3). These results confirmed the findings of Osman et al (2002) and Gorfu et al (2003) who found that there was a clear improvement in nitrogen uptake when phosphorus was added on wheat. The results of this study indicated no effect of the applied PR and TSP on leaf potassium content (Table 3). These results were in line with those reported by Abdalla (1993) and El Saeed (1997) on sorghum. This may be attributed to the belief that the soils of Sudan have enough available potassium. This investigation showed that the addition of PR or TSP significantly $(\mathrm{P}>0.05)$ increased available soil phosphorus with increasing level of the PR and TSP in both seasons (Table 4). This was expected because the phosphatic fertilizers are of low recoveries ( $\cong 20 \%)$, hence, the rest remains in the soil which may raise the levels of soil phosphorous on extraction (Elsheik et al 2005).

In the residual experiment, the application of PR or TSP significantly increased $(\mathrm{P}>0.05)$ plant height (Table 1). These results were in conformity with those of Menon et al (1995), who tested the residual efficiency of PR and TSP stating that plant height is increased with the fertilizer rate. Table 2 shows that the application of PR and TSP significantly increased $(\mathrm{P}>0.05)$ shoot and root dry weights in the residual experiment These results agreed with the findings of Pastrana (1994) who concluded that after a five-year experiment, on an acid soil, the effect of PR and TSP in first year was the same as that at the end of the experiment.

Table3. The effect of phosphate rock and triple super phosphate on leaf nitrogen, phosphorus and potassium \%:

\begin{tabular}{|c|c|c|c|c|c|c|c|c|c|}
\hline \multirow{2}{*}{$\begin{array}{c}\text { Season } \\
\text { Treatment } \\
\mathrm{Kg} \mathrm{P}_{2} \mathrm{O}_{5} \mathrm{ha}^{-1}\end{array}$} & \multicolumn{3}{|c|}{ First season } & \multicolumn{3}{|c|}{ Second season } & \multicolumn{3}{|c|}{ Residual Effect } \\
\hline & N\% & $\mathrm{P} \%$ & $\mathrm{~K} \%$ & $\mathrm{~N} \%$ & $\mathrm{P} \%$ & $\mathrm{~K} \%$ & $\mathrm{~N} \%$ & $\mathrm{P} \%$ & $\mathrm{~K} \%$ \\
\hline \multicolumn{10}{|c|}{ Phosphate Rock } \\
\hline Control & $1.20 \mathrm{c}$ & $0.16 \mathrm{~b}$ & $0.99 \mathrm{a}$ & $1.10 \mathrm{c}$ & $0.16 \mathrm{c}$ & $1.10 \mathrm{a}$ & $1.40 \mathrm{~b}$ & $0.13 \mathrm{c}$ & $0.85 \mathrm{a}$ \\
\hline 55 & $1.30 \mathrm{~b}$ & $0.16 \mathrm{a}$ & $1.07 \mathrm{a}$ & $1.20 \mathrm{~b}$ & $0.18 \mathrm{~b}$ & $1.10 \mathrm{a}$ & $1.50 \mathrm{a}$ & $0.14 \mathrm{~b}$ & $0.87 \mathrm{a}$ \\
\hline 110 & $1.40 \mathrm{a}$ & $0.17 \mathrm{a}$ & $0.96 \mathrm{a}$ & $1.30 \mathrm{a}$ & $0.18 \mathrm{a}$ & $1.20 \mathrm{a}$ & $1.50 \mathrm{a}$ & $0.16 \mathrm{a}$ & $0.88 \mathrm{a}$ \\
\hline $\mathrm{LSD}_{0.05}$ & 0.056 & 0.0056 & 0.1062 & 0.702 & 0.0065 & 0.1022 & 0.0623 & 0.009 & 0.1176 \\
\hline \multicolumn{10}{|c|}{ Triplesuper phosphate } \\
\hline 45 & $1.31 \mathrm{~b}$ & $0.17 \mathrm{a}$ & $1.00 \mathrm{a}$ & $1.20 \mathrm{a}$ & $0.17 \mathrm{~b}$ & $1.10 \mathrm{a}$ & $1.50 \mathrm{~b}$ & $0.15 \mathrm{a}$ & $0.88 \mathrm{a}$ \\
\hline 110 & $1.34 \mathrm{a}$ & $0.17 \mathrm{a}$ & $1.10 \mathrm{a}$ & $1.20 \mathrm{a}$ & $0.19 \mathrm{a}$ & $1.20 \mathrm{a}$ & $1.60 \mathrm{a}$ & $0.15 \mathrm{a}$ & $0.82 \mathrm{a}$ \\
\hline $\mathrm{LSD}_{0.05}$ & 0.056 & 0.0056 & 0.1062 & 0.702 & 0.0065 & 0.1022 & 0.0623 & 0.009 & 0.1176 \\
\hline
\end{tabular}

Means with similar letter(s) in each column are not significantly different at 0.05 probability level according to LSD 
Table 4. The effect of phosphate rock and triplesuperphosphate on available soil phosphorus (ppm)

\begin{tabular}{|lccc|}
\hline $\begin{array}{c}\text { Treatment } \\
\mathrm{Kg} \mathrm{P}_{2} \mathrm{O}_{5} \\
\mathrm{ha}^{-1}\end{array}$ & $\begin{array}{c}\text { First sea- } \\
\text { son }\end{array}$ & $\begin{array}{c}\text { Second } \\
\text { season }\end{array}$ & $\begin{array}{c}\text { Residual } \\
\text { effect }\end{array}$ \\
\hline \multicolumn{4}{c}{ Phosphate Rock } \\
Control & $3.8 \mathrm{c}$ & $3.6 \mathrm{c}$ & $3.1 \mathrm{~b}$ \\
55 & $4.6 \mathrm{~b}$ & $4.0 \mathrm{~b}$ & $3.6 \mathrm{a}$ \\
110 & $4.8 \mathrm{a}$ & $4.6 \mathrm{a}$ & $3.7 \mathrm{a}$ \\
$\mathrm{LSD}_{0.05}$ & 0.27 & 0.34 & 0.34 \\
& Triplesuperphosphate & \\
$\mathrm{Control}$ & $3.8 \mathrm{c}$ & $3.3 \mathrm{c}$ & $2.70 \mathrm{~b}$ \\
45 & $4.4 \mathrm{~b}$ & $3.9 \mathrm{~b}$ & $3.80 \mathrm{a}$ \\
90 & $5.1 \mathrm{a}$ & $5.0 \mathrm{a}$ & $3.96 \mathrm{a}$ \\
$\mathrm{LSD}_{0.05}$ & 0.27 & 0.34 & 0.34 \\
\hline
\end{tabular}

Means with similar letter(s) in each column are not significantly different at 0.05 probability level according to LSD.

The effect of previously applied PR or TSP was evident on leaf phosphorus content (Table 3). The results indicated a significant rise of leaf phosphorus which may be due to the increased solubility of phosphorus from different sources with time, hence, enhancing the absorption of phosphate anion. These findings are in harmony with those of Abdalla (1993). Moreover, the available soil phosphorus of the previously fertilized pots was significantly $(\mathrm{P}>0.05)$ increased over the control (Table 4). This was found in agreement with many previous research results (Pastrana 1994 and El Saeed 1997). Similarly, Abekoe and Sahrawat (2003) reported similar results in Ultisol of West Africa on rice crop. Since the recovery of phosphate fertilizers is often low (less than $25 \%$ ) and loss of $\mathrm{P}$ by leaching or gaseous evolution is negligible, the unused $\mathrm{P}$ must build up in the soil, providing erosion does not take place. Although most of the added phosphate fertilizers may seem to be unavailable to first crop, its effect can last a long time (Warren 1992).

In conclusion, the results of this study revealed that the plant measurements obtained from PR treatment were comparable to those obtained from TSP treatments. Therefore, PR can be considered as a potential source of phosphorus for crops.

\section{REFERENCES}

Abekoe, M.K. and K.L. Sahrawat (2003). Longterm cropping effect on phosphorus fractions in an Ultisol of the humid forest zone in Western Africa. Communication in Soil Science and Plant Analysis 34(3-4): 427-437.

Abdalla, I.A. (1993). Investigation on the Use of Nuba Mountains Phosphate Rocks in Agriculture. pp 20- 23. M.Sc. Thesis. Faculty of Agriculture, University of Khartoum, Shambat, Sudan,

El Saeed, Y.H. (1997). The Effect of Phosphate Rock, Triplesuperphosphate and their Combinations on the Performance of Sorghum bicolor var. dura (L.). $x$ Sorghum Sudanese (piper) stapf). pp. 85- 90. M.Sc. Thesis, Faculty of Agriculture, University of Khartoum, Shambat, $\mathrm{Su}-$ dan.

Elsheik M.A.; A.M.A Eltilib and E.A.E. Elsheik (2005). A note on the effect of phosphate rock, triplesuperphosphate, Bradyrhizobium and their combinations on the available soil phosphorus in Shambat clay soil. U. of K. J. Agric. Sci. 13(3): 488-493.

El Tilib, A.M.A; M.A. Abadalla and M.E. Abdelhafeez (2003). Wheat response to partially acidified phosphate rock, triplesuperphosphate and their combinations in vertisols in Sudan. Gezira Journal of Agricultural Science, 1(1): 11-22.

Gorfu A.; R.F. Kuhne; D.G. Tanner and P.L.G. Vlek (2003). Recovery of 15 N-labelled urea applied to wheat (Triticum aestivum L.) in Ethiopian highlands as affected by Phosphorus fertilization. Journal of Agronomy and Crop Science, 189(1): 30-38.

Hago, T.E.M. and B.M. Osman (1999). Effect of nitrogen and phosphorus on some quality attributes of Roselle (Hibiscus sabdariffa var. sabdariffa L.) under irrigation. University of Khartoum Journal of Agriculture Science, 7(2): 16-24.

Hago, T.E.M.; A.A. Abdel Bagi and F.E. Ahmed (2002). Response of Roselle (Hibiscus sabdariffa var. sabdariffa L.) to nitrogen, phosphorus and Sulphur under Summer and Winter sowing.Unversity of Khartoum. Journal of Agriculture Science 10(1): 40-52.

Hammond, S.H.; S.H. Chein and Easter Wood (1986). Agronomic effectiveness of Bayovar phosphate rock in soil with induced phosphate 
retention. Soil Science Society of America Journal, 50: 1601-1606.

Menon, R.G.; S.H. Chien and S.D.T. Hellum (1995). Iron and aluminum oxide influence on agronomic effectiveness of modified phosphate rocks. Soil Science Society of America Journal 59(6):1762-1762.

Osman, E; J.P. Muir and A. Elgersma (2002). Effect of Rhizobium inoculation and phosphorus application on native texas legumes grown in local soil. Journal of Plant Nutrition 25 (1): 75-92.

Pastrana, L. (1994). Response of Brach aria decubents to application of two phosphorus sources on acid soil. Pastures Tropical 16 (1): 32-35.

Tandon, H.L.S. (1993). Methods of Analysis of Soils, Plants, Waters and Fertilizers. Fertilizers Development and Consultation Organization, New Delhi (India).

Warren, G.P. (1992). Fertilizer phosphorus: sorption and residual value in Tropical African soils. NRI Bulletin 37, Chatham, UK: Natural Resources Institute, Central Avenue, Chatham Mari time, Kent, ME44 TB, United Kingdom. 